NBER WORKING PAPER SERIES

\title{
GLOBAL SAVINGS AND GLOBAL INVESTMENT: THE TRANSMISSION OF IDENTIFIED FISCAL SHOCKS
}

\author{
James Feyrer \\ Jay C. Shambaugh \\ Working Paper 15113 \\ http://www.nber.org/papers/w15113 \\ NATIONAL BUREAU OF ECONOMIC RESEARCH \\ 1050 Massachusetts Avenue \\ Cambridge, MA 02138 \\ June 2009
}

We thank seminar participants at Dartmouth College for helpful suggestions. We thank Daniel Keum for research assistance and helpful conversations. All errors are the authors. The views expressed herein are those of the author(s) and do not necessarily reflect the views of the National Bureau of Economic Research.

NBER working papers are circulated for discussion and comment purposes. They have not been peerreviewed or been subject to the review by the NBER Board of Directors that accompanies official NBER publications.

(C) 2009 by James Feyrer and Jay C. Shambaugh. All rights reserved. Short sections of text, not to exceed two paragraphs, may be quoted without explicit permission provided that full credit, including $\odot$ notice, is given to the source. 
Global Savings and Global Investment: The Transmission of Identified Fiscal Shocks

James Feyrer and Jay C. Shambaugh

NBER Working Paper No. 15113

June 2009

JEL No. E2,E21,E22,F15,F32,F36,F41,F42

\begin{abstract}
This paper examines the effect of exogenous shocks to savings on world capital markets. Using the exogenous shocks to US tax policy identified by Romer \& Romer, we trace the impact of an exogenous shock to savings through the income accounting identities of the US and the rest of the world. We find that exogenous tax increases are only partially offset by changes in private savings (Ricardian equivalence is not complete). We also find that only a small amount of the resulting change in US saving is absorbed by increased domestic investment (contrary to Feldstein \& Horioka). Almost half of the fiscal shock is transmitted abroad as an increase in the US current account. Positive shocks to US savings generate current account deficits and increases in investment in other countries in the world. We cannot reject that the shock is uniformly transmitted across countries with different currency regimes and different levels of development. The results suggest highly integrated world capital markets with rapid adjustment. In short we find that the US acts like a large open economy and the world acts like a closed economy.
\end{abstract}

\author{
James Feyrer \\ Department of Economics \\ Dartmouth College \\ 6106 Rockefeller Hall \\ Hanover, NH 03755-3514 \\ and NBER \\ james.feyrer@dartmouth.edu \\ Jay C. Shambaugh \\ Dartmouth College \\ Department of Economics \\ 6106 Rockefeller Hall \\ Hanover, NH 03755 \\ and NBER \\ jay.c.shambaugh@dartmouth.edu
}




\section{Introduction}

Recent discussions of a global savings glut suggest that a surge in savings in one country can have impacts across the globe1 We wish to examine what happens when a dollar of savings is added to world capital markets. If we treat the world as a closed economy, undergraduate macroeconomics suggests that an exogenous increase in savings results in an increase in investment of equal size. Is this evident in the data? Do all countries in the world see an increase in investment or are some countries cut off from shocks to world capital markets?

In this paper we exploit a series of exogenous shocks to US fiscal policy identified by Romer and Romer (2009b) as a starting point to examine the impact of a shock to world savings. The Romer shocks are useful because they use analysis of the legislative record to identify tax changes that were unrelated to contemporaneous economic conditions. The path from a change in US tax policy to world savings requires examining a number of interesting questions. Do US tax changes affect aggregate savings in the US? Are changes in US savings exported abroad or does all adjustment occur domestically?

The analysis in this paper is grounded in the national income accounting identities of the United States and the rest of the world. By definition,

$$
\bar{Y}=C(\bar{Y}-T)+I+G+C A
$$

where output, $\bar{Y}$, is assumed to be determined by the natural rate of output, consumption, $C$, is a function of disposable income, investment, $I$, is a function of the interest rate in world capital markets, $G$ is government spending, and $C A$ is the current account. Savings is what is left over after the private sector and the government consume.

$$
S=\bar{Y}-C(\bar{Y}-T)-G
$$

The relationship between the current account, saving, and investment is

$$
C A=S-I .
$$

\footnotetext{
${ }^{1}$ See Bernanke (2007) for a discussion of the global savings glut hypothesis. The argument posited that an oversupply of savings - particularly in Emerging Asia - helped generate a US current account Deficit as the savings had to flow somewhere, and the US was the willing recipient of the savings.
} 
We wish to trace the impact of exogenous changes in taxes through these accounting identities. Equation (2) shows that a change to taxes will affect savings through private consumption. If agents assume that tax changes are permanent, standard models of consumption suggest that a tax increase will result in decreased consumption and increased national savings.

Barro (1974) suggests that forward looking taxpayers take into account the government's long run budget constraint and therefore do not respond to tax changes that are unaccompanied by changes in government spending. 2 We will refer to this private savings response as Ricardian Equivalence for the remainder of the paper. If Ricardian equivalence holds perfectly, tax shocks will be perfectly absorbed by changes to private savings and there will be no impact on national savings. Thus, we need to test whether national savings in the US is affected by the tax shocks.

Second, are shocks to US national savings transmitted across borders? Equation (3) shows that changes to savings must appear either as domestic investment shifts or changes to the current account. Feldstein and Horioka (1980) find that savings and investment tend to be highly correlated across countries 3 If US savings and investment comove perfectly, the shock to US saving will be absorbed domestically and not transmitted across the border.

These two questions combine to determine whether we observe "twin deficits." Are budget deficits linked with current account deficits? If we see an impact of US tax shocks on the US current account, this signals that neither Ricardian equivalence nor Feldstein-Horioka are fully operational and there is some truth to the view of twin deficits.

Once we establish that exogenous shocks to US savings are transmitted abroad through the US current account we can begin to take accounting identities seriously at the world level. Barring trade with Mars, a shock to the US current account must generate an equal and opposite shock to the aggregate current account of the rest of the world. Equation (3) tells us that these current account shocks must be accompanied by changes in saving or investment in the rest of the world.

We find that exogenous tax policy changes in the US have a significant impact on

\footnotetext{
${ }^{2}$ Also see Barro (1989). Ricardian Equivalence has generated a considerable literature since Barro's initial article. See Elmendorf and Mankiw (1999) and Seater (1993) for some details of the debate.

${ }^{3}$ This result has been updated countless times. See Coakley, Kulasi and Smith (1998). Obstfeld and Taylor (2005) note that the Feldstein and Horioka (1980) correlation has been falling since 1970.
} 
investment in other countries over the period 1973 to 2005 . When the US changes tax policy for exogenous reasons, a substantial amount of that change in policy is transmitted through changes in the current account to the rest of the world. When the US government saves more, private citizens do save somewhat less, but the impact on national savings is still positive. Further, domestic investment has a relatively small response to an exogenous fiscal shock, so the majority of the change in savings turns into a change in net lending to or borrowing from the rest of the world.

Fiscal shocks in the US act as shocks to world savings. The response of the rest of the world to these shocks appears to be well described by the simple closed economy relationship $\mathrm{S}=\mathrm{I}$. An exogenous shock to world savings results in higher investment around the globe. While there is some suggestion that the magnitude of the response varies across currency regimes or levels of development, we cannot reject that all countries have identical responses to the shocks. Interestingly, the magnitude of the response seems to be unrelated to standard measures of openness to capital flows.

These results are consistent with a world where shocks to the world capital market are transmitted to all countries and all countries share a similar elasticity of investment with respect to the world interest rate. Every additional dollar of world savings appears as an investment increase in each country in the world proportional to their share of world GDP. This is consistent with short run equalization of capital returns and is similar to the long run equalization to capital returns found in Caselli and Feyrer (2007).

The results suggests that world capital markets are fluid and reach into all countries in the world. Changes in saving in one country rapidly appear as investment increases in all the rest of the countries in the globe. This is important for thinking about the importance of East Asian savings over the last decade as well as for evaluating the impact of the large fiscal policy changes currently occurring in the large economies in the world.

\section{Previous Literature}

Much of the literature on fiscal policy transmission rightly focuses on the impact of such policy on the country that engages in the fiscal changes. Such work has included 
looking at episodes of defense budget expansion (Ramey (2006), etc.) to examine the impact of fiscal changes on consumption and wages. This work tends to find output increases with a fiscal expansion, but consumption and real wages fall. Further evidence is drawn from short run restriction identified vector autoregressions. This work includes Blanchard and Perotti (2002), Perotti (2007), and Mountford and Uhlig (2008). In this work, output rises with a positive fiscal shock, but so do real wages and consumption. The recent debate on the impact of fiscal policy has often focused on this disagreement.

In our work, we take the changes in tax policy identified by Romer and Romer (2009b) as exogenous to current economic conditions to be our fiscal shocks. Romer and Romer (2009b) focus on the changes over time for the economy as a whole as well as for investment and other outcomes following a fiscal shock. They find that tax increases which are purely exogenous to the economic setting are contractionary. They focus on the dynamic response to tax shocks and see that GDP, Consumption and Investment all fall in response to a tax increase, with the impact on Investment building over time. In further work, they examine the response of govt expenditures (Romer and Romer (2009a)). They find that even in the long run, government expenditures do not respond strongly to changes in taxes - the starve the beast hypothesis does not hold. This result is important in the context of our work in that it suggests changes in government taxes are not simply offset by changes in spending in which case there would have been no impact on government savings.

A number of studies have looked at the international transmission of fiscal shocks. There are two main groups of this literature. First, some papers test the direct impact of a fiscal shock in one country on the GDP of another's. This literature is testing the question of whether fiscal policy shocks can act as an "engine of growth" for the rest of the world, or whether the shocks are primarily limited to the local country (see Bénassy-Quéré and Cimadomo (2006) and Arin and Koray (2005))

A second strand of the literature is more directly related to the twin deficit concept. This literature also relies on accounting identities to show that changes in government savings should lead to changes in the current account. Work using calibrations tends to support this view, but recent time series econometric evidence has failed to find such effects. In particular, both Kim and Roubini (2008) and Corsetti and Muller (2008) argue they find evidence of twin divergence not twin deficits. That is, they find that fiscal shocks identified through short run restrictions 
VARs (in the same manner as the bulk of the domestic literature) do not generate twin deficits, instead, budget deficits lead to real exchange rate depreciations and current account surpluses (or no impact). As Kim and Roubini (2008) note, the change in government savings appears to go both to changes in private savings and changes in investment (crowding out, consistent with Feldstein and Horioka (1980)). Corsetti and Muller (2008) also examine evidence across countries to see if the persistence of the shocks and openness of the economy affect the transmission. They find that yes, such factors play a role and the US has relatively small levels of international transmission of shocks based on its relatively closed economy.

Related work has considered both the twin deficits and global savings glut arguments. Chinn and Ito (2007) and Gruber and Kamin (2007) have explored the broader determinants of current accounts. Both use panel analysis to determine the root determinants of countries' current account to GDP ratios. Chinn and Ito (2007) are supportive of twin deficits, finding coefficients of between 0.2 and 0.5 on the budget deficit. Gruber and Kamin (2007) find a coefficient of 0.09 on the fiscal balance. Neither study has exogenous variation to identify the impact of a fiscal change, but instead rely on cross-country differences. Also, both are examining medium term determinants, using five year averages in the panel.

Given that savings in one country can affect investment in another and vice versa, barring any exogenous variation, it is difficult for these studies to directly estimate a global savings glut relationship. Instead, they look to see if East Asia saves more than expected and the US less. Gruber and Kamin (2007) argue Asia does save too much currently, but that this can be explained as a reaction to the East Asian crisis. Chinn and Ito (2007) also argue there is too much savings in Asia but note this does not appear to be due to a lack of financial development. Both papers argue it is unclear why so much of this savings would flow to the US.

The results which are skeptical of twin deficits contrast with a finding in Romer and Romer (2009b). At the end of their paper, Romer and Romer examine the impact of a tax change on exports and imports. They find that exports increase and imports decrease, which they view as consistent with a tax increase leading to a drop in interest rates and hence reducing capital inflows. But, they argue, the drop in imports may simply be more consistent with a fall in income rather than any open economy effects.

We take this observation as a starting point to explore the impact of a change 
in government savings in one country on both the current account and investment in other countries. Our paper is unique in bringing different evidence to bear than most explorations of twin deficits: exogenous fiscal shocks matching actual policy changes. We find that there is in fact evidence along the lines a twin deficit theory would predict: changes in government savings are correlated with changes in the current account. Thus, we can look at exogenous shocks to taxes in the United States as exogenous shocks to savings available to the rest of the world. The next section explains those shocks and how we examine the effects. We further expand the literature by looking not just at the current account of the country with the change, but also by examining where the increased savings goes around the world. Thus, the paper makes an important contribution to the literature studying how changes in savings in one country affect other countries.

\section{Methodology}

We borrow the shocks from Romer and Romer (2009b). The construction of the shocks is described in more detail in Romer and Romer (2008). They use legislative history to separate out tax changes that were made based on attempts to respond to current economic situations from those that are exogenous to current economic conditions. Such changes may be motivated by a desire to raise taxes in an effort to restore long run budgetary balance or to cut taxes to lower marginal rates and possibly spur long run economic growth. Crucially, the changes are not aimed at smoothing short run business cycle fluctuations. Examples include changes in

social security tax rates aimed at long run balance, tax cuts motivated by a shift in governing ideology, or tax increases aimed at long run budget balance. Romer and Romer argue such changes are exogenous to current or anticipated economic situations. There is, for example, no relationship between the shocks and lagged GDP growth in the US (see Figure 1).

The exogeneity is crucial to the Romer and Romer examination of the domestic effects of tax changes. It is also crucial to our investigation of the impact of those changes on US savings, investment, and the current account. Even if one worries that there is some component of endogeneity in these shocks, when we examine overseas responses, the changes are even more clearly exogenous. The shocks are in no way responses to changes in savings, investment, or general economic circumstances in 
Figure 1: Romer Fiscal shocks versus lagged GDP growth

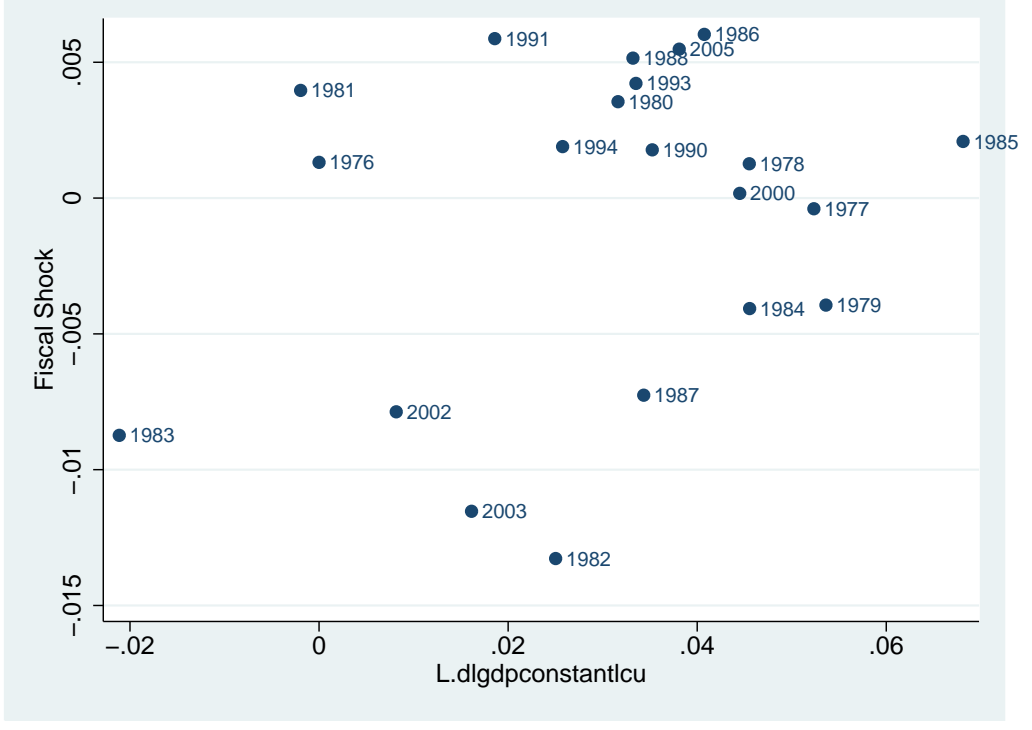

other countries.

We limit ourselves to those shocks in the post Bretton Woods era of the international economy. Our reason is that changes in the international financial architecture over time arguably make looking at the international economic transmission prior to that time less informative for more recent experiences. Further, we begin to lose data on current accounts, investment, and other necessary variables for an increasing number of countries as we expand back before the 1970's. Thus our sample runs from 1973 to 2005. For the regression on the current account, the dataset is an unbalanced panel of 113 countries. The investment data is somewhat more limiting with only 106 countries. For the current account, Kuwait has changes that are greater than aggregate GDP for several years around the Gulf War. For this reason, we exclude Kuwait from the data set.

We explore the impact of the Romer shocks on US variables, rest of world variables summed together, and in panels for individual country/year observations. We examine the data in terms of changes divided by GDP. That is, when we look at the current account, we examine the change in the current account divided by the previous year's GDP. The advantage of scaling to GDP rather than simply using raw dollar amounts and controlling for GDP is that when we turn to the effects in other countries, we do not have to convert investment into a common currency. 
Instead, we can scale by local GDP 4

By using lagged GDP to scale the changes we are implicitly assuming that GDP is unchanged by the shocks. Romer and Romer (2009b) find that the impact on output is quite small in the first three quarters after the shock. Assuming no output movement is therefore a reasonable assumption during the year of the tax change which is our period of interest. More importantly, output effects are likely to bias us against finding external effects of US tax changes. If output falls with a tax increase, private savings should decrease such that national savings will increase by less than if there were no output response. The same bias will hold for the impact of the shocks on non US GDP, and foreign GDP is even less likely to respond to the shocks than domestic GDP.5

The shocks themselves are in Billions of US dollars and are changes in tax policy. That is, a permanent reduction in taxes by 100 Billion dollars in 1985 would show up as a shock of -100 Billion in 1985 and zero thereafter. Thus, we are interested in the change in the current account (or investment) in a given year. Romer and Romer (2009b) typically use a dynamic specification examining the impact of policy changes over time. We lack adequate quarterly data for many countries to exploit their series higher frequency and use annual data, removing part of the interest in fluctuations over time. More importantly, our view is that of an accounting identity. We are curious where the changes in savings in a given year go. If the government saves more in a given year, where does that money go in that given year. For ease of comparison across countries and time, we scale the shocks as well as the changes in the current account and investment by GDP.

\section{Results}

\subsection{Aggregate Results}

Figure 2 shows the crucial motivating fact. The bars represent the exogenous shocks to US fiscal policy identified by Romer and Romer (2009b). The two lines show

\footnotetext{
${ }^{4}$ The current account data are in current dollars and the change is expressed as a percentage of lagged current dollar GDP. Investment data are real dollars and the change is expressed as a percentage of lagged real GDP. All data are from the World Bank World Development Indicators.

${ }^{5}$ If GDP responds contemporaneously a US tax increase would reduce world aggregate demand and drive down investment in the rest of the world. This would bias against finding that US tax increases generate investment increases elsewhere.
} 
Figure 2: Changes in the US and Rest of World Current Accounts in Response to US Fiscal Policy Shocks



changes in the US current account and changes in the summation of the current accounts for the rest of the world. In order to maintain consistency with the tables in the rest of the paper, all changes and shocks are scaled to the level of non-US world GDP. For the purpose of this graph, the important fact is that the relative magnitudes are the same for the shock and for the current account changes.

Exogenous changes in US fiscal policy track reasonably closely with changes in the size of the US current account. The simple correlation between the fiscal shocks and changes to the US current account is 0.28 . The correlation between the shocks and changes to the rest of the world's current account is -0.36 . Trade with Mars appears to play a small role and the correlation between the movements in the US current account and the rest of the world's current account is -0.76 .

Table 1 illustrates the basic facts from Figure 2 more formally. We regress the change in the current account divided by lagged GDP on the shock measured as a percentage of GDP. The regressions are run with Newey-West standard errors to control for possible serial correlation in the time series 6 For the current account,

\footnotetext{
${ }^{6}$ As it turns out Newey-West standard errors, heteroscedasticity robust standard errors, and OLS estimated standard errors are all nearly identical. There is very little autocorrelation in either
} 
Table 1: The Effect of Exogenous Shocks to US Fiscal Policy on the Current Account and Investment in the US and the Rest of the World (ROW)

\begin{tabular}{|c|c|c|c|c|c|}
\hline & $\begin{array}{c}\text { (1) } \\
\text { US CA }\end{array}$ & $\begin{array}{c}(2) \\
\text { US Inv }\end{array}$ & $\begin{array}{c}(3) \\
\text { ROW CA }\end{array}$ & $\begin{array}{c}(4) \\
\text { ROW CA }\end{array}$ & $\begin{array}{c}(5) \\
\text { ROW CA-IV }\end{array}$ \\
\hline Fiscal Shock / US GDP & $\begin{array}{l}0.466^{*} \\
(0.190)\end{array}$ & $\begin{array}{c}0.166 \\
(0.327)\end{array}$ & & & \\
\hline US CA & & & $\begin{array}{c}-0.764^{* *} \\
(0.132)\end{array}$ & & $\begin{array}{c}-1.260^{* *} \\
(0.454)\end{array}$ \\
\hline Fiscal Shock / ROW GDP & & & & $\begin{array}{c}-0.643^{* *} \\
(0.217)\end{array}$ & \\
\hline Constant & & $\begin{array}{l}0.006^{*} \\
(0.002)\end{array}$ & & & \\
\hline Observations & 32 & 29 & 32 & 32 & 32 \\
\hline R-squared & & & & & 0.317 \\
\hline
\end{tabular}

the expected change in any given time period is zero so a constant is omitted. For investment, aggregate GDP growth causes growth over time, so a constant is included 7 Equation (4) shows the simple estimating equation.

$$
y_{t}=\alpha+\beta * S h o c k_{t}+\epsilon
$$

What coefficients should we expect to see for the US regressions in Table 1]? If the US were a small open economy and government spending, private savings, and investment within the US were completely unresponsive to exogenous fiscal shocks we would expect these shocks to translate one for one into changes in the US current account. This suggests that we should see a coefficient of one in column (1) and a coefficient of zero in column (2).

However, for the response of investment we must remember that the US is not a small open economy. In a typical year in our sample, US GDP is roughly $25 \%$ of total world output. A substantial portion of the shock to US savings should therefore show up in US investment even if there were no strong tendency of savings and investment to move together (as suggested by Feldstein and Horioka (1980)). In fact, if capital were perfectly mobile and all countries had identical elasticities the shocks or the changes in the current account.

${ }^{7}$ Results including a constant in all regressions are available on request. The difference from the reported results is quite small. 
of investment to movements in the common world interest rate, we would expect the US investment increase to be proportional to the US share of world GDP 8 The benchmark for the coefficient in the investment regression should therefore be roughly 0.25 . This in turn suggests that the benchmark for the response of the current account in column (1) is 0.75 rather than one.

Column (1) shows the response of the US current account to an exogenous fiscal shock. The coefficient of 0.466 indicates that for every dollar increase in US taxes collected, almost half moves to the rest of the world economy through an increase in the US current account. Column (2) shows the response of US investment to the fiscal shocks. For every 1 dollar increase in US taxes collected there is a 17 cent increase in investment in the US.99

In neither case can we reject our benchmarks of 0.75 for the current account and 0.25 for investment. The investment coefficient is not precisely estimated, so the confidence interval allows for some degree of saving-investment correlation along the lines of Feldstein and Horioka. However, the point estimates suggest no effect. The current account coefficient is somewhat less than 0.75 and the investment coefficient suggests that this is not due to correlation between savings and investment. This is consistent with some degree of Ricardian Equivalence. The point estimates suggest that for every dollar of tax increase, about one third of the tax increase is offset by a decrease in private savings. Of the remaining 67 cents, roughly 17 is invested in the US and the rest, or roughly half the shock, is transmitted abroad 10

Columns (3) through (5) examine the response of the current account in the rest of the world to shocks originating in the US. The left hand side in these regression is the change in the sum of the value of the current accounts for all countries except the US expressed as a percentage of aggregate GDP summed across all countries except the US. In other words it is the change in the value of the non US current account as a percentage of non US GDP.

In order to aid in interpreting the coefficients, the right hand side variables are also scaled as a proportion of non US GDP. For example, Column (3) examines the

\footnotetext{
${ }^{8}$ This fact that savings and investment should be more highly correlated in large open economies has been noted in the literature going back to Feldstein and Horioka (1980). See Coakley et al. (1998) for a more complete discussion.

${ }^{9}$ Romer and Romer (2009b) find that a tax increase is coincident with a drop in investment over time. The contemporaneous effect is close to zero. We are using data set only from 1973 forward at the annual frequency, so the slightly different result is not surprising.

${ }^{10}$ The 17 cents that show up as domestic investment is almost exactly 25 percent of the savings change, matching the US share of world income.
} 
response of the rest of the world's current account to changes in the US current account. The change in the US current account is measured as a percentage of non-US aggregate GDP. As long as the sum of the current accounts of all countries in the world is zero (no trade with Mars) this coefficient should be exactly negative one. If the US current account increases by 1 percent of non US GDP, we would expect the non US current account to decrease by 1 percent as a percentage of non US GDP. The actual estimate is -0.76 . The coefficient is significantly different from zero at the one percent level and is not significantly different from negative 1.

Column (4) examines the effect of the fiscal shock on the rest of the world's current account. The fiscal shock is also scaled as a percentage of non US GDP. In this case we do not expect a coefficient of negative one since not all of the shock will cross the US border. As we discuss above, the largest response (in absolute value) that we expect to see is 0.75 , and column (1) suggests that only half of the fiscal shock appears as an increase in world savings. Assuming that column (1) is well estimated and that there are no other effects of a US fiscal shock we should expect the coefficient in column (4) to be negative and of the same size as the coefficient in column (1). The estimate of -0.643 is larger in absolute value than the column (1) estimate and smaller than our theoretical benchmark and insignificantly different from neither. We can strongly reject a zero coefficient or no response.

Finally, we can use the fiscal shock as an instrument to establish that exogenous changes in the US current account results in equal and opposite changes in the current account in the rest of the world. Column (5) regresses the non US current account response to a change in the US current account where the US current account change in instrumented with the Romer and Romer exogenous fiscal shocks. In this case, accounting identities would once again suggest a coefficient of negative one. The point estimate is larger (in absolute value) than one, but unity is well within the confidence interval, and once again, we can safely reject no effect.

The results of Table 1 suggest that exogenous shocks to US fiscal policy act as a shock to world savings. There is a statistically significant and economically sensible response of the rest of the world's current account to a US tax law change. A one dollar increase in US taxes results in a 47 cent shock to the US current account representing an exogenous shock to world savings. This increase in world savings shows up as a current account surplus for all other countries in the world. 


\subsection{Disaggregated Results}

What impact does a increase in world savings have on a typical country? Suppose that our benchmark is to think of the world as comprised of countries that rely on a common pool of savings and respond to a common world interest rate. At the world level, savings must equal investment, so shocks to world savings should result in increased investment through lower world interest rates. As long as investment decisions in individual countries are determined by the world interest rate, we should expect to see all countries in the world respond to shocks to world savings. If we further assume that countries borrow from abroad at the margin and share similar elasticities of investment with regard to the world interest rate we should expect to see a proportionally similar response across all countries. Even if countries insulate themselves from the world interest rate to some extent via capital controls or have different levels of nominal interest rates due to different inflation rates and expected changes in exchange rates, as long as the shock to world savings and hence world interest rates has an impact at the margin of their capital market, we should see some response.

In the tables to follow we move from aggregate results to individual country results. One advantage is to allow us to scale local investment by local GDP and not have to sum investment across countries (which involves finding plausible internationally comparable investment price indices). For the initial results, we include results where observations are weighted by country size. In these cases, the regressions are similar to the aggregated regressions from the previous section. This has the advantage of scaling the coefficients to conform to the accounting identities discussed earlier. A one dollar shock to the US current account should show up as a one dollar shock to the rest of the world's current account. The downside to this approach is that the response of large countries will dominate the results. For the non-weighted regressions each country is taken as an individual experiment, increasing the power of the regressions. This will also allow us to examine sub-groups of countries for differential responses. Do open countries respond to a world saving shock differently than closed countries? Does the currency regime affect the response to shocks? Do shocks differ over levels of development?

Table 2 shows the results from our country level regressions. Figures 3 and 4 show the corresponding partial scatterplots of the residual changes in the current 
account and investment versus the residual of the US fiscal shocks 11 The regression equation being estimated is similar to equation (4) with the addition of country fixed effects made possible by the panel structure of the data. The country level effects are only included in the regressions on changes to investment. Because of GDP growth, the change in investment as a percentage of GDP is positive on average and will vary by country based on the growth rate of aggregate GDP. The country effects control for this heterogeneity. In the case of the current account, our accounting identities suggest that the expected growth rate for any arbitrary observation is zero. In leaving out country effects and a constant we are essentially imposing this moment condition on the current account regressions 12 In all cases standard errors are clustered by year to account for the fact that the shock is identical for all countries in any given year 13

$$
y_{i t}=\beta * \text { Shock }_{i t}+\gamma_{i}+\epsilon
$$

As in Table 1 we expect a coefficient of between -0.47 and -0.75 on the current account. If smaller countries typically respond more, the coefficient on the unweighted regressions will tend to be larger, with the weighted regressions more directly corresponding to the aggregated results.

The unweighted regression has a clearly larger coefficient and the size implies that when the US increases taxes by one percent of world GDP, the typical country sees a current account response in excess of one percent of its GDP, though one percent is in the confidence interval. For the weighted regressions, the responses are directly between -0.47 and -0.75 and -0.47 is well within the confidence interval. For both the weighted and unweighted regressions, zero effect is strongly rejected.

The expected coefficient on investment is less certain. If we believe other countries current accounts must respond to a change in the US current account simply due to an adding up constraint, the open question is whether the change in the cur-

\footnotetext{
${ }^{11}$ The coefficients and significance levels do not change as we eliminate outliers to zoom in on a more visible relationship in the bottom half of the figures.

${ }^{12}$ The results do not change substantially if we include a full set of country dummies. When included, the estimate for the constant are small and typically insignificant.

${ }^{13}$ The other potential standard error complication is serial correlation. The aggregate results suggest that this is not a significant issue. Clustering on the country level rather than the year level yields much lower standard errors. Using multilevel clustering on both year and country (as described in Cameron, Gelbach, Miller, Hall and Drive (2006)) yields standard errors that are very similar to just clustering by year.
} 
Figure 3: Changes in Current Account in response to US Fiscal Policy Shocks
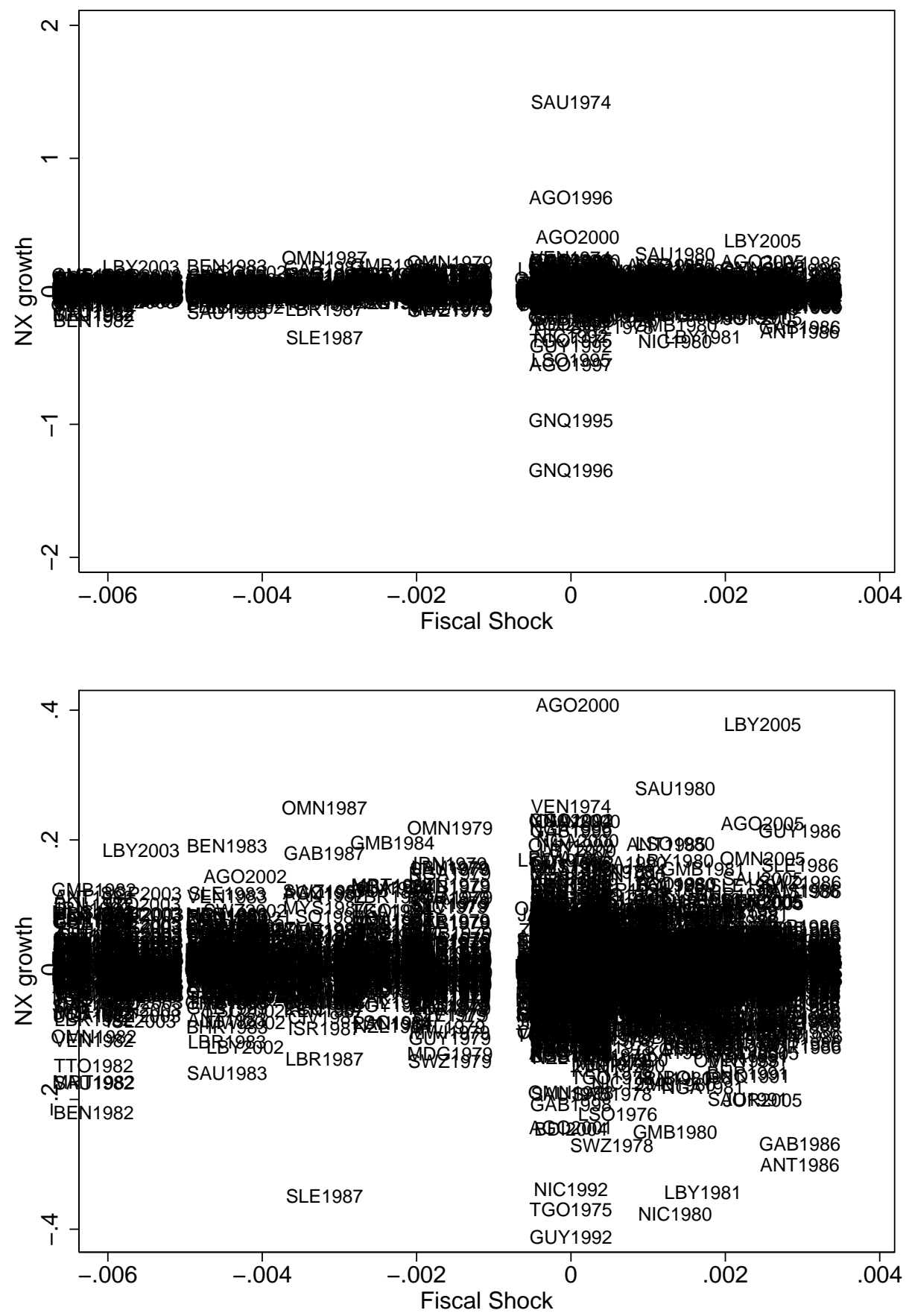
Figure 4: Changes in investment in response to US Fiscal Policy Shocks
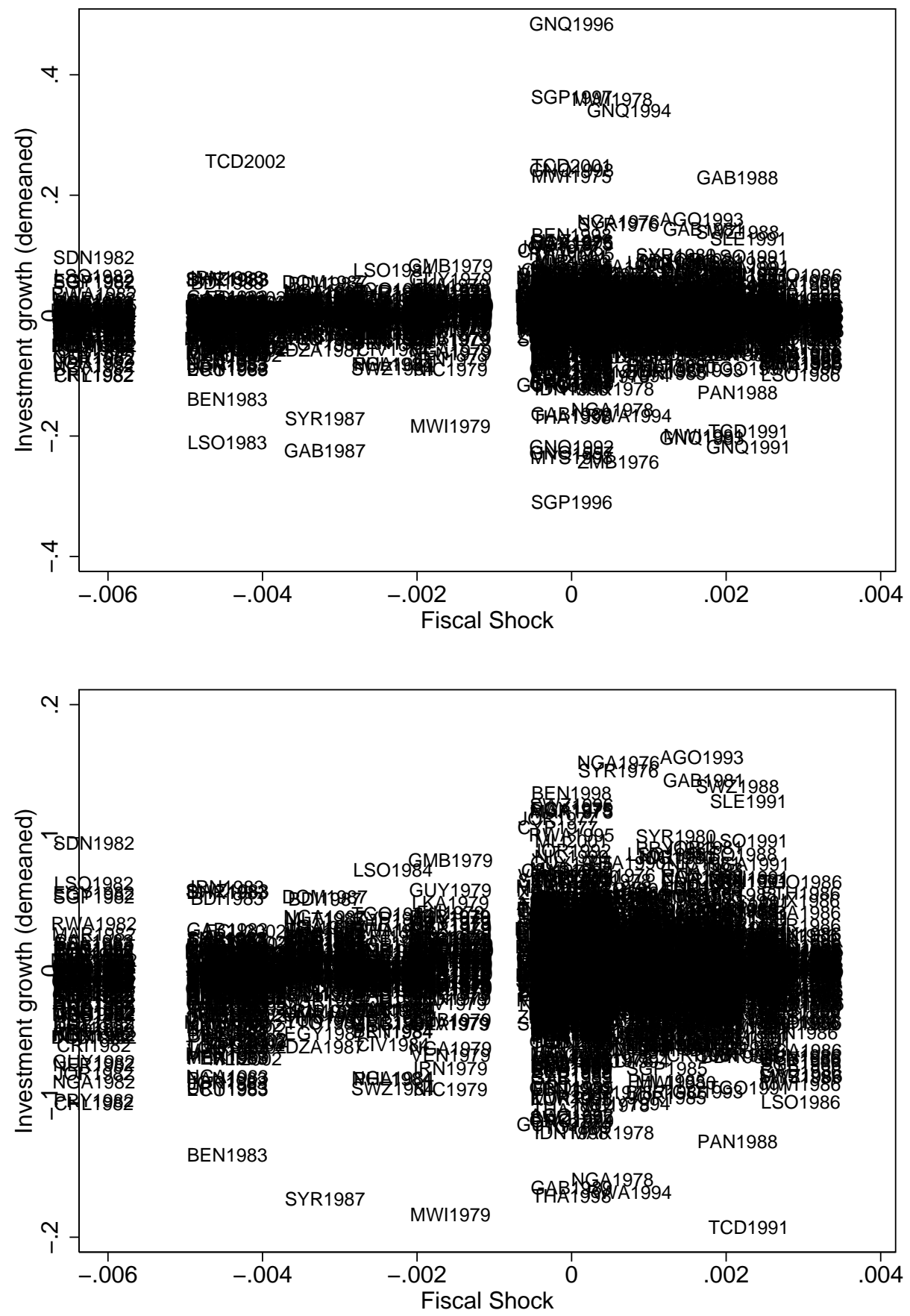
Table 2: The Effect of US fiscal shocks on investment and the current account

\begin{tabular}{lcccc}
\hline & $(1)$ & $(2)$ & $(3)$ & $(4)$ \\
& CA & CA weight & INV & INV weight \\
\hline Fiscal Shock & $-1.630^{* *}$ & $-0.581^{*}$ & $1.250^{*}$ & 0.930 \\
& $(0.486)$ & $(0.279)$ & $(0.594)$ & $(0.548)$ \\
Constant & & & $0.010^{* *}$ & $0.199^{*}$ \\
& & & $(0.002)$ & $(0.084)$ \\
Observations & 3002 & 2994 & 2588 & 2558 \\
R-squared & 0.003 & 0.001 & 0.129 & 0.058 \\
\hline \multicolumn{4}{c}{${ }^{* *} \mathrm{p}<0.01,{ }^{*} \mathrm{p}<0.05,+\mathrm{p}<0.1$} &
\end{tabular}

Investment regressions include a set of country dummies. Standard errors clustered by year.

rent account is accomplished by a change in investment or savings abroad. Thus, we might expect a coefficient of roughly the same size (but opposite sign) for investment (since $\mathrm{CA}=\mathrm{S}$ - I ) if there is no savings response but a smaller response if savings moves.

Columns (3) and (4) of table 2 suggest that the current account shocks are absorbed through changes to investment, not savings. The investment response is always close to the absolute value of the current account response. A US fiscal shock of one percent of non-US world GDP is accompanied by roughly the same size increase in investment abroad. As with the current account regressions, the coefficient for the unweighted regression is larger than the weighted regression, but the gap is not substantial.

A slightly different way to look at the same question is directly through the current account. Table 3 shows the result of using the exogenous fiscal shock as an instrument for shocks to the current account. In columns (1) and (2) the change in the current account as a percentage of own country GDP is regressed against the changes in the US current account divided by GDP in the rest of the world. The US current account change is instrumented with the exogenous fiscal shock. In columns (3) and (4) the change in investment at the country year level is regressed against the change in the current account at the country year level with the current account change instrumented using the US fiscal shock.

Table 3 is similar to Table 2 with the coefficients rescaled to more closely match the accounting identities. Since the sum of the world's current account must be zero, we expect the coefficient on the weighted regression in column (2) to be negative one. 
Table 3: The Effect of Current Account Shocks - IV

\begin{tabular}{|c|c|c|c|c|}
\hline & $\begin{array}{l}\text { (1) } \\
\text { CA }\end{array}$ & $\begin{array}{c}(2) \\
\text { CA weight }\end{array}$ & $\begin{array}{c}(3) \\
\text { INV }\end{array}$ & $\begin{array}{c}(4) \\
\text { INV weight }\end{array}$ \\
\hline US CA Change / World GDP & $\begin{array}{c}-3.063^{* *} \\
(1.067)\end{array}$ & $\begin{array}{c}-1.137^{* *} \\
(0.372)\end{array}$ & & \\
\hline CA change / GDP & & & $\begin{array}{c}-0.579^{* *} \\
(0.202)\end{array}$ & $\begin{array}{l}-1.048 \\
(0.696)\end{array}$ \\
\hline Constant & & & $\begin{array}{c}0.001 \\
(0.010)\end{array}$ & $\begin{array}{l}-0.039 \\
(0.040)\end{array}$ \\
\hline $\begin{array}{l}\text { Observations } \\
\text { R-squared }\end{array}$ & 3002 & 2994 & $\begin{array}{l}2268 \\
0.013\end{array}$ & 2266 \\
\hline
\end{tabular}

For investment, a coefficient of negative one in the weighted regressions indicates that the current account shock is completely absorbed by investment with no change in savings 14 These are roughly the values that we observe. For the average country we see highly statistically significant responses in the current account when US fiscal shocks are used to instrument US current account movements. For the average country we see statistically significant responses in investment to domestic current account movements that are caused by US fiscal shocks.

Exogenous fiscal shocks in the US appear to cause movements in the US current account which cause changes to investment in the rest of the world. In the next section we move to smaller samples of the data to examine whether there is heterogeneity in how countries are affected by the shock. In particular we will examine whether levels of development, currency regimes, or levels of financial openness affect the size of the response to US fiscal shocks.

\subsection{Does the Shock Affect Countries Symmetrically?}

Table 4 shows the results broken up by level of development where the advanced countries are the original OECD countries, the emerging countries are the countries

\footnotetext{
${ }^{14}$ Note that the sign of the investment coefficients is flipped compared to the reduced form table (2) because the right hand side variable is now the domestic current account. In table 2 the coefficients are the response of investment to a world savings shock. In table 3 the coefficients represent the response of investment to a domestic current account shock. These will run in opposite directions.
} 
Table 4: Responses by Level of Development

\begin{tabular}{lcccc}
\hline & \multicolumn{4}{c}{ Current Account } \\
& All & Advanced & Emerging & Developing \\
\hline Fiscal Shock & $-1.630^{* *}$ & $-0.775+$ & -1.471 & $-1.992^{* *}$ \\
& $(0.486)$ & $(0.448)$ & $(0.996)$ & $(0.582)$ \\
Observations & 3002 & 651 & 600 & 1751 \\
R-squared & 0.003 & 0.006 & 0.002 & 0.003 \\
\hline \multicolumn{4}{c}{ Investment } \\
& All & Advanced & Emerging & Developing \\
\hline Fiscal Shock & $1.250^{*}$ & 0.562 & $1.841^{*}$ & 1.329 \\
Observations & $(0.594)$ & $(0.530)$ & $(0.688)$ & $(0.853)$ \\
R-squared & 2588 & 634 & 534 & 1420 \\
\hline & 0.129 & 0.024 & 0.049 & 0.148 \\
\hline
\end{tabular}

Investment regressions include a set of country dummies. Standard errors clustered by year.

in the EMBI index along with much of Eastern Europe, and the developing counties are all other countries 15 For the current account, the response to US fiscal shocks appear to be decreasing in levels of development, though one cannot reject that all three groups have identical coefficients. For investment, the emerging group appears to have the largest response, but again one cannot reject that all three groups are identical. Perhaps more interesting than the pattern of results is the fact that countries at all three levels of development have a significant response to the US shocks to world savings (significant for the Advanced and Developing samples for the current account and for the Emerging sample in investment) and that the magnitudes of these results are very similar across levels of development. Initially, one might think that large advanced nations have such deep capital markets that outside fiscal shocks would be moot, but one must consider the global savings glut argument that an increase in savings abroad affects a country even as large and financially deep as the US. In that context, it may not be surprising that US shocks spill across all types of nations.

Table 5 shows the results broken down by currency regime. The currency regime is categorized across two dimensions. First, are countries dollar based or non-dollar based and second, are they pegged or are they nonpegged. We use the coding from Shambaugh (2004) for both measures. The base country is the country to

\footnotetext{
${ }^{15}$ See table 7 in the appendix for a full list of countries in each category.
} 
which a nation pegs or if it is not pegged in a given year, the country to which it pegs when it does peg. Given that nearly every country pegs at some point in the sample, the base country is directly revealed. In questionable cases, the history of the currency and behavior of nearby countries can be used as a guide. Countries are considered pegged if they stay within 2 percent bands against their base currency throughout the year or if they have a perfectly flat exchange rate except for a one time devaluation 16

The results suggest that dollar based economies have a larger response to both the current account and investment compared to non dollar based economies. Pegs have a somewhat larger response than floats. Dollar based pegs have the largest response for both variables and it is only for the dollar based countries that we can reject no effect. While this variation seems reasonable, none of these differences is significant. It may be that dollar based and dollar pegged countries are more tied to the US capital market and hence feel the impact of US tax shocks more directly, but in general, the coefficients are within range of one another, so no definitive statements can be made. The only significantly different coefficient is that nondollar nonpegs show effectively zero response in investment, but that coefficient is imprecisely estimated and we cannot reject zero or one or negative one for that matter.

Table 6 shows the variation in responses across financially open and closed economies. In this table, we use the binary measure of the IMF's annual yearbook to classify countries (aggregating the disaggregated measures into a binary classification after 1995 for continuity). Closed economies appear to have a larger response in the current account but a smaller response to investment. The standard errors are fairly high across groups leaving the differences insignificant. The results, though, do not change substantially if one uses continuous measures developed by Edwards or Chinn and Ito (2006)17 to divide countries into groups. It seems odd that even countries that nominally have capital controls are affected by changes in US tax policy, but few countries with capital controls truly shut off access to capital markets. Instead, they tend to temper price signals or simply slow capital flows. In fact, a number of studies suggest that capital controls do not substantially alter the

\footnotetext{
${ }^{16}$ See Klein and Shambaugh (2009) for an extensive discussion of the different ways to code a country's exchange rate regime.

${ }^{17}$ Also see Chinn and Ito (2008).
} 
Table 5: Responses by Currency Regime

\begin{tabular}{|c|c|c|c|}
\hline & $\begin{array}{l}(1) \\
\text { All }\end{array}$ & $\begin{array}{c}(2) \\
\text { Dollar } \\
\text { Based } \\
\end{array}$ & $\begin{array}{c}(3) \\
\text { non Dollar } \\
\text { Based } \\
\end{array}$ \\
\hline & \multicolumn{3}{|c|}{ Current Account } \\
\hline & \multicolumn{3}{|c|}{$\overline{A l l}$} \\
\hline Fiscal Shock & $\begin{array}{c}-1.630^{* *} \\
(0.486)\end{array}$ & $\begin{array}{c}-1.844^{* *} \\
(0.639)\end{array}$ & $\begin{array}{l}-1.283^{*} \\
(0.622)\end{array}$ \\
\hline Observations & 3002 & 1851 & 1151 \\
\hline \multirow[t]{2}{*}{ R-squared } & 0.003 & 0.004 & 0.002 \\
\hline & \multicolumn{3}{|c|}{ Pegs } \\
\hline Fiscal Shock & $\begin{array}{c}-1.837^{*} \\
(0.728)\end{array}$ & $\begin{array}{c}-2.032+ \\
(1.172)\end{array}$ & $\begin{array}{l}-1.614 \\
(0.968)\end{array}$ \\
\hline Observations & 1298 & 658 & 640 \\
\hline \multirow[t]{2}{*}{ R-squared } & 0.002 & 0.003 & 0.002 \\
\hline & \multicolumn{3}{|c|}{ Non Pegs } \\
\hline Fiscal Shock & $\begin{array}{c}-1.436^{*} \\
(0.670)\end{array}$ & $\begin{array}{c}-1.727^{*} \\
(0.786)\end{array}$ & $\begin{array}{l}-0.788 \\
(0.535)\end{array}$ \\
\hline Observations & 1701 & 1193 & 508 \\
\hline \multirow[t]{3}{*}{ R-squared } & 0.004 & 0.005 & 0.003 \\
\hline & \multicolumn{3}{|c|}{ Investment } \\
\hline & \multicolumn{3}{|c|}{ All } \\
\hline Fiscal Shock & $\begin{array}{l}1.250^{*} \\
(0.594)\end{array}$ & $\begin{array}{l}1.735^{*} \\
(0.733)\end{array}$ & $\begin{array}{c}0.535 \\
(0.803)\end{array}$ \\
\hline Observations & 2588 & 1564 & 1024 \\
\hline \multirow[t]{2}{*}{ R-squared } & 0.129 & 0.051 & 0.199 \\
\hline & \multicolumn{3}{|c|}{ Pegs } \\
\hline Fiscal Shock & $\begin{array}{l}1.419+ \\
(0.745)\end{array}$ & $\begin{array}{l}1.848^{*} \\
(0.808)\end{array}$ & $\begin{array}{c}1.043 \\
(1.211)\end{array}$ \\
\hline Observations & 1046 & 513 & 533 \\
\hline \multirow[t]{2}{*}{ R-squared } & 0.206 & 0.137 & 0.232 \\
\hline & \multicolumn{3}{|c|}{ Non Pegs } \\
\hline Fiscal Shock & $\begin{array}{c}1.066 \\
(0.630)\end{array}$ & $\begin{array}{l}1.587+ \\
(0.812)\end{array}$ & $\begin{array}{c}0.046 \\
(0.717)\end{array}$ \\
\hline Observations & 1542 & 1051 & 491 \\
\hline R-squared & 0.074 & 0.079 & 0.066 \\
\hline
\end{tabular}

Investment regressions include country dummies. Standard errors clustered by year. 
Table 6: Responses by Financial Openness

\begin{tabular}{lccc}
\hline & \multicolumn{3}{c}{ Current Account } \\
& All & Open & Closed \\
\hline Fiscal Shock & $-1.630^{* *}$ & -0.726 & $-2.048^{* *}$ \\
& $(0.486)$ & $(0.995)$ & $(0.568)$ \\
Observations & 3002 & 749 & 2068 \\
R-squared & 0.003 & 0.001 & 0.005 \\
\hline \multicolumn{3}{c}{ Investment } \\
& All & Open & Closed \\
\hline Fiscal Shock & $1.250^{*}$ & $1.564^{*}$ & $1.019+$ \\
Observations & $(0.594)$ & $(0.706)$ & $(0.598)$ \\
R-squared & 2588 & 729 & 1859 \\
\hline \multicolumn{3}{c}{$* *$ p $<0.01,{ }^{*} \mathrm{p}<0.05,+\mathrm{p}<0.1$} \\
Investment regressions include country dummies. \\
\multicolumn{2}{c}{ Standard errors clustered by year. }
\end{tabular}

volume of capital flows for a country (though they may alter the composition) 18 In that context, we may not be surprised to see similar responses across different types of financial openness measures.

In fact, all that is needed to have symmetric responses across different country types is marginal lending from world markets and similar elasticities of investment with regards to world interest rates across countries. This is consistent with the conclusion of Caselli and Feyrer (2007) which shows that financial returns to capital are roughly equalized across countries. If returns are equalized at the margin, this suggests that shocks should transmit across all countries in a similar fashion. This is largely what we observe.

\section{Conclusion}

This paper takes a straightforward approach to examining the transmission of fiscal shocks across borders using accounting identities. We view changes in tax policy as a change in government savings. Assuming that change in savings is not entirely offset by either private savings or investment, the current account should respond

\footnotetext{
${ }^{18}$ See for example, a number of papers in the book Edwards (2007). In particular, the chapters by Magud and Reinhart (2007) makes the point directly, but other country studies suggest the same result.
} 
to such a shock. If the home current account changes, the foreign must as well. A tax shock in one country should therefore lead to changes in either savings or investment (or both) in other countries.

Using exogenous tax policy shocks in the US developed by Romer and Romer (2009b), we find that when US taxes increase, a substantial (roughly half) portion of that increase in savings is transmitted to the current account. That increase in the US current account is mirrored in a current account deficit abroad. There appears to be little change in foreign savings. Instead, investment abroad moves nearly one for one with the current account. Thus, fiscal contraction through tax increases may lead to increased investment abroad. The result is novel both in itself and due to the approach through which it is reached. Due to the intertwined nature of savings and investment around the globe, previous work studying the change in savings in one country has not been able to identify the impact on other countries' investment.

One might expect that if a large country increased taxes, that fiscal contraction may act as a drag on the world economy. But, if that increase in savings also increases investment in other countries, such an effect may be mitigated. In a domestic context, we tend to think one reason a tax cut does not purely crowd out investment is the ability to borrow from abroad. In the global context, though, the world economy is closed, so a change in taxes has a substantial impact on investment.

Along the way to this important result, the paper has implications for a number of important theories. The fact that a tax policy change affects the US current account suggests that neither Ricardian equivalence nor the Feldstein Horioka result hold completely. Our results also suggest that the notion of twin deficits appears sensible despite some recent econometric evidence to the contrary. Most of all, though, our results suggest that savings shocks in one country affect investment around the globe.

The implications for today's world are important. According to these results, tax cuts in one country will lower the pool of savings available for investment around the globe. We caution that our identification is from tax changes that are exogenous with respect to current economic conditions under the assumption of output at the natural rate. This is clearly not the case with fiscal policy in the first half of 2009 . It may be that the short run response to changes in fiscal policy is very different in periods of slack aggregate demand compared to an economy operating at the natural rate of output. Ultimately, however, the economy will be operating at or 
near the natural rate and the accounting identities continue to hold. 
Table 7: List of Countries by Level of Development

\begin{tabular}{lllll} 
Advanced & Emerging & Developing & & \\
\hline Australia & Argentina & Afghanistan & Gambia, The & Neth. Antilles \\
Austria & Brazil & Algeria & Ghana & Nicaragua \\
Belgium & Chile & Angola & Guatemala & Niger \\
Canada & Colombia & Bahamas, The & Guinea & Nigeria \\
Denmark & Egypt & Bahrain & Guyana & Oman \\
Finland & Hong Kong & Bangladesh & Haiti & Panama \\
France & India & Barbados & Honduras & Paraguay \\
Germany & Indonesia & Benin & Iran & Qatar \\
Greece & Israel & Bolivia & Jamaica & Romania \\
Iceland & Korea, Rep. & Burkina Faso & Jordan & Rwanda \\
Ireland & Malaysia & Burundi & Kenya & Senegal \\
Italy & Mexico & Cameroon & Lao PDR & Sierra Leone \\
Japan & Pakistan & Central Afr Rep. & Lebanon & Sri Lanka \\
Luxembourg & Peru & Chad & Lesotho & Sudan \\
Netherlands & Philippines & Congo, Dem. Rep. & Liberia & Swaziland \\
New Zealand & Saudi Arabia & Costa Rica & Libya & Syrian Arab Rep \\
Norway & Singapore & Cote d'Ivoire & Madagascar & Tanzania \\
Portugal & South Africa & Cyprus & Malawi & Togo \\
Spain & Thailand & Dominican Rep. & Mali & Trinidad \& Tobago \\
Sweden & Turkey & Ecuador & Malta & Tunisia \\
Switzerland & Venezuela & El Salvador & Mauritania & Uganda \\
United Kingdom & & Equatorial Guinea & Mauritius & United Arab Emir. \\
& & Ethiopia & Morocco & Uruguay \\
& & Fiji & Myanmar & Zambia \\
& & Gabon & Nepal &
\end{tabular}




\section{References}

Arin, K.P. and F. Koray, "Fiscal Policy and Economic Activity: US Evidence," LSU Working paper, 2005.

Barro, Robert J., "Are government bonds net wealth?," Journal of political economy, 1974, 82 (6), 1095.

_ , "The Ricardian Approach to Budget Deficits," The Journal of Economic Perspectives, 1989, 3 (2), 37-54.

Bénassy-Quéré, A. and J. Cimadomo, "Changing Patterns of Domestic and Cross-Border Fiscal Policy Multipliers in Europe and the US," cepii working paper, 2006.

Bernanke, B., "Global Imbalances: Recent Developments and Prospects," Bundesbank Lecture, Berlin, Germany, 2007.

Blanchard, O. and R. Perotti, "An Empirical Characterization of the Dynamic Effects of Changes in Government Spending and Taxes on Output*," Quarterly Journal of Economics, 2002, 117 (4), 1329-1368.

Cameron, A.C., J.B. Gelbach, D.L. Miller, M.C. Hall, and O.S. Drive, "Robust inference with multi-way clustering," NBER working paper, 2006.

Caselli, Francesco and James Feyrer, "The Marginal Product of Capital," Quarterly Journal Of Economics, May 2007, CXIII (2), 535-568.

Chinn, M.D. and H. Ito, "What matters for financial development? Capital controls, institutions, and interactions," Journal of Development Economics, 2006, 81 (1), 163-192.

and _ _ , "Current account balances, financial development and institutions: Assaying the world saving glut," Journal of International Money and Finance, 2007, 26 (4), 546-569.

and _ _ "A new measure of financial openness," Journal of Comparative Policy Analysis: Research and Practice, 2008, 10 (3), 309-322.

Coakley, J., F. Kulasi, and R. Smith, "The Feldstein-Horioka puzzle and capital mobility: A review," International Journal of Finance \& Economics, 1998, 3 (2), 169 .

Corsetti, G. and G.J. Muller, "Twin deficits, openness, and the business cycle," Journal of the European Economic Association, 2008, 6 (2-3), 404-413.

Edwards, Sebastian, Capital controls and capital flows in emerging economies: policies, practices, and consequences, University Of Chicago Press, 2007. 
Elmendorf, Douglas W. and Gregory N. Mankiw, "Government debt," Handbook of Macroeconomics, 1999, 1, 1615-1699.

Feldstein, M. and C. Horioka, "Domestic saving and international capital flows," The Economic Journal, June 1980, pp. 314-329.

Gruber, J.W. and S.B. Kamin, "Explaining the global pattern of current account imbalances," Journal of International Money and Finance, 2007, 26 (4), $500-522$.

Kim, S. and N. Roubini, "Twin deficit or twin divergence? Fiscal policy, current account, and real exchange rate in the US," Journal of International Economics, 2008, 74 (2), 362-383.

Klein, Michael and Jay Shambaugh, Exchange Rate Regimes in the Modern Era, Cambridge: MIT Press, 2009.

Magud, Nicolas and Carmen M. Reinhart, "Capital Controls: An Evaluation," in Sebastian Edwards, ed., Capital controls and capital flows in emerging economies: policies, practices, and consequences, University Of Chicago Press, 2007.

Mountford, Andrew and Harald Uhlig, "What are the Effects of Fiscal Policy Shocks?," Working Paper 14551, National Bureau of Economic Research December 2008.

Obstfeld, M. and A.M. Taylor, Global capital markets: integration, crisis, and growth, Cambridge University Press, 2005.

Perotti, Roberto, "In Search of the Transmission Mechanism of Fiscal Policy," Working Paper 13143, National Bureau of Economic Research June 2007.

Ramey, V.A., "Identifying Government Spending Shocks: Its All in the Timing," Manuscript, University of California, San Diego, 2006.

Romer, C.D. and D.H. Romer, "A Narrative Analysis of Postwar Tax Changes," Unpublished manuscript, University of California, Berkeley (April), 2008.

and __ "Do Tax Cuts Starve the Beast: The Effect of Tax Changes on Government Spending," Brookings Papers on Economic Activity, 2009.

and _ _ "The macroeconomic effects of tax changes: estimates based on a new measure of fiscal shocks," $A E R$, forthcoming 2009.

Seater, John J., "Ricardian Equivalence," Journal of Economic Literature, 1993, $31(1), 142-190$. 
Shambaugh, Jay C., "The Effect of Fixed Exchange Rates on Monetary Policy*," Quarterly Journal of Economics, 2004, 119 (1), 301-352. 